\title{
La écfrasis metaléptica: recurso representacional en Una novelista en el Museo del Louvre, de Zoé Valdés ${ }^{1}$
}

Por: Magíster Iraida L. Bárzaga Morales², Universidad de Concepción, Chile

Recibido: 8 de diciembre, 2017.

Aprobado: 12 de marzo, 2018.

\section{Resumen}

Con este trabajo se pretende demostrar que la novela Una novelista en el Museo del Louvre (2009) está estructurada a partir del recurso retórico e intertextual "écfrasis metaléptica", categoría acuñada por Luz Aurora Pimentel (2012), que configura una distribución museográfica en la que el relato se construye como guion, para desacralizar el discurso político insular y, a la vez, instalar la novela, en su doble plástico y narrativo, como discursos insurrectos y críticos del status quo cubano. La relación intertextual o intermedial establecida entre la representación literaria y la visual, entonces, es de carácter contributivo, porque las imágenes que se evocan mediante la escritura se transforman en iconotextos que incrementan el valor icónico del discurso.

\section{Abstract:}

The ekphrasis metaleptica: representational resource in Una novelista en el Museo del Louvre, of Zoé Valdés

With this work we intend to demonstrate that the novel Una novelista en el Museo del Louvre (2009) is structured from the rhetorical and intertextual resource "ekphrasis metaleptica", category coined by Luz Aurora Pimentel (2012); that configures a museographic distribution in which the story is constructed as a script, to desacralize the insular political discourse, while installing the novel, in its plastic and narrative double, as insurrectionary discourses and critics of the Cuban status quo. The intertextual or intermedial relation established between the literary and visual representation, then, is of a contributory nature because the images that are evoked through writing are transformed into iconotexts that increase the iconic value of the discourse.

1 Este trabajo forma parte de una investigación mayor denominada "Apuntes sobre la dimensión museal de la literatura latinoamericana o los museos de papel" (Proyecto FONDECYT $\mathrm{N}^{\circ}$ 11121221), cuyo investigador responsable es el Dr. Juan D. Cid Hidalgo.

2 Iraida Bárzaga es Magíster en Literaturas Hispánicas, graduada en la Universidad de Concepción, Chile. Actualmente es investigadora FONDECYT y estudiante del Doctorado en Literaturas Latinoamericanas en la Universidad de Concepción, Chile. Contacto: irabm1987@ gmail.com.

PALABRAS CLAVE:

Écfrasis metaléptica, intertextual, intermedial, iconotextual, recurso representacional, guion museográfico, curadora

\section{KEY WORDS:}

Ekphrasis metaleptica, intertextual, intermedial, iconotextual, representational resource, museographic script, curator 


\section{INTRODUCCIÓN}

En los últimos tiempos, están siendo visibles diversos análisis que asumen la écfrasis como recurso intertextual que atraviesa la escritura de múltiples autores. Sin embargo, el origen de esta forma retórica data de tiempos primigenios. En esta investigación se emplea el término "écfrasis", que es uno de los usos aceptados en castellano. Pero, es común encontrar también el término "ecfrasis" sin tilde en castellano y en inglés "ekphrasis" o "ékphrasis", siendo este último el que posee mayor similitud con el vocablo griego original "Éxффoorı". El término fue acuñado por vez primera en los Progymnasmata de los siglos I al IV d.C., donde se consideraba como una descripción-narración sobre cualquier tema que tenía la virtud vívida de poner el objeto frente a los ojos. Es decir, dotaba de vida al relato, acercando al lector para crear una imagen visual de manera que produjera en él el mismo efecto que si estuviera ante el original. Estas descripciones vívidas con el paso de los años se dispusieron en torno a objetos plásticos de carácter figurativo, de modo que en las teorías literarias contemporáneas el concepto se circunscribió solamente a la descripción de objetos de artes visuales en literatura (para mayores antecedentes se recomienda el reciente trabajo de Begoña Alberdi, "Escribir la imagen: la literatura a través de la écfrasis" en Literatura y Lingüística $N^{\circ} 33$, pp. 17-38). Es en este marco que se inscribe esta investigación que pretende dar cuenta de los recursos narrativos empleados por la escritora cubana Zoé Valdés en Una novelista en el Museo del Louvre (2009) [a partir de aquí, cuando se cite de la novela objeto de estudio Una novelista en el Museo del Louvre, solo se colocará el número de la página y no la ficha completa].

La crítica académica no ha reparado de manera constante sobre la obra de esta autora y menos aún, sobre este relato, solo en determinados momentos y en textos muy puntuales, lo cual no significa que sus creaciones carezcan de méritos y en ellas no aparezcan reflejados recursos que cautiven a los lectores. Con estas páginas se pretende revelar el proyecto narrativo de la escritora cubana desde una mirada crítica a dicha labor. En este intento por escudriñar los elementos composicionales, los argumentos y los "secretos" de la novela, se busca reflexionar sobre algunas formas posibles de entendimiento entre lo plástico y lo literario, línea de acceso que se inscribe en los centros de interés de la intermedialidad, iconotextualidad, intertextualidad; todos ellas herramientas a las que se recurre en el análisis de "lo plástico" en la novela.

Zoé Valdés se apropia del recurso ecfrástico para desplegar su proceso escritural dinámico con lo que establece una especie de juego a partir de la ficción plástica aludida. Para analizar la poética empleada por la autora en la novela objeto de estudio se asume este recurso como configurador de la trama narrativa, la que a su vez constituye una verdadera invitación a una lectura iconotextual que dota de múltiples resignificaciones e interpretaciones a la novela. Con respecto a esto, vale destacar que la descripción narrativa de cuadros plásticos dinamiza las redes de referencia del lector, el cual se ve en la necesidad de proyectar mucho de su acervo en el acto de lectura. Dinámica en la cual los personajes de las obras de arte transgreden la frontera del contexto que los define, lo que provoca que se subvierta el estatuto canónico de las figuras que protagonizan las obras de artes visuales, de los personajes y de la narradora.

El intertexto, a través de una forma de écfrasis (écfrasis metaléptica), atraviesa el discurso de esta narración y desempeña un rol esencial en ella. La écfrasis es perceptible -entonces- como registro "tasador" de la ficción que subvierte el estatuto canónico de los personajes y las figuras de artes visuales citadas, creando espacios de representación literaria con los cuales el lector es deleitado, a la vez que puesto en un rol "creativo", pues comparte la focalización del narrador, quien se encuentra curatoriando una exposición: la novela. Desde su posición de narradora exiliada, la novelista remite a la idea de identidad diaspórica junto a la elaboración de un discurso de fuerte sentido feminista. Líneas temáticas que son recurrentes, aunque de manera solapada, en la prolífera obra literaria de Valdés. Por ende, la pregunta de investigación que guiará esta propuesta es la siguiente: ¿Qué importancia tiene el empleo de la écfrasis metaléptica en el despliegue de la novela que inventarea una serie de obras plásticas universales? 
Con esta propuesta investigativa se busca poner en valor la escritura de la novelista cubana-española Zoé Valdés, demostrar que el relato se construye fundamentalmente a través de écfrasis metaléptica, que inscribe el proyecto narrativo en una interzona en que arte y literatura despliegan diálogos y relaciones de enorme interés.

Este estudio académico a Una novelista en el Museo del Louvre, como se ha señalado, centra su atención en la representación verbal de obras de artes visuales, es decir, en el recurso retórico-discursivo denominado écfrasis metaléptica, entendido como configurador de una escritura que privilegia las relaciones intertextuales o intermediales que se establecen entre ambas representaciones, a la vez que explicitar su carácter productivo, ya que las imágenes evocadas se convierten en iconotextos, con lo cual se establece una férrea, intensa y fuerte relación que produce un incremento icónico. En las siguientes páginas se pretende acercar al lector a una nueva línea de acceso a la escritura de Zoé Valdés, que viene a complementar las lecturas parciales desde la perspectiva de género, la condición exiliar y la búsqueda identitaria.

\section{LOS OJOS DE LA PALABRA: APROXIMACIONES AL CONCEPTO DE ÉCFRASIS}

La preocupación de la literatura por "presentar una descripción-narración sobre cualquier tema que tenía la virtud vívida de poner el objeto frente a los ojos" (Pimentel, 2003, p. 281) se percibió desde la cultura helenística. Es en este contexto que se acuñó la palabra écfrasis (ekphrasis), término griego que "en su sentido etimológico significa la acción propia de hacer comunicable o de facilitar el acceso y el acercamiento a algo" (Agudelo, 2012, p. 72); de manera que la descripción de una escena o de un objeto tenía como finalidad hacer evidente con palabras aquello que estaba ausente.

Entre 1711 y 1714, la descripción del escudo de Aquiles, realizada por Pope, constituyó la primera écfrasis de la cual se tuvo referencias en la historia de la literatura debido a la maestría con la que fue descrito, que fue "pintado" en las líneas del poema épico sin tener existencia real. La investigadora Ana Lía Gabrieloni (destacada investigadora, profesora y crítica literaria argentina, miembro del Centro Interdisciplinario de Estudios Europeos en Humanidades (CIEHUM), que ha realizado diversos estudios vinculados a la relación entre la literatura y las artes visuales), expone: "la primera écfrasis que conocemos en la historia de la literatura dejó de presentarse exclusivamente como un escudo-cuadro-monumento para estar revestida con características de documento" (2008, p. 86).

Por otro lado, en la tradición grecolatina, especialmente la desarrollada por los progymnasmata o ejercicios de retórica para entrenar a los alumnos en la práctica de la escritura, la écfrasis quedó definida como "una descripción extendida, detallada, vívida, que permitía presentar el objeto ante los ojos; una descripción que tenía la virtud de la enargeia" (Pimentel, 2003, p. 205). Es decir, los maestros griegos de retórica enseñaban y empleaban la écfrasis como un ejercicio a través del cual se describía un objeto, una persona o un lugar de forma precisa y muy detallada, de tal manera que el oyente creyera estar ante él.

Tomando en consideración lo enunciado, es perceptible que la écfrasis -en este contexto antiguotenía como rasgo principal atribuirle vida y movilidad al relato, haciendo más asequible la lectura en tanto el lector fuese capaz de crear una imagen visual a partir de lo interpretado. Con el paso del tiempo y la llegada de la modernidad, estas descripciones vívidas se fueron extendiendo a obras de artes figurativas, siendo los objetos la esencia de la descripción, mientras que las acciones en sí mismas conformaban la narración.

Hacia mediados del siglo XX, el vasto pasado retórico de esta figura sufrió una profunda reinterpretación con la teoría de Leo Spitzer (1962), donde plantea que "la écfrasis es la descripción poética de una obra de arte pictórica o escultórica" (p. 72). A partir de esta interpretación, en el 2003 Pimentel plantea que la écfrasis adquirió el carácter de género literario y algunos años más tarde, Murray Krieger (1967) la eleva a un principio general de la poética.

En las últimas décadas se ha podido notar una abundante reflexión acerca de la lectura de las imágenes en una era mediática, donde se ha instalado 
la primacía de la mirada (Mitchell, Barthes, Eco, Greimas, Panofsky, Praz, Gali). Es por ello que se considera necesario y productivo:

Constatar las relaciones entre novela y artes visuales que nos llevan a interrogar las fronteras y fisuras que van de la imagen al texto y viceversa, es decir, con qué mecanismos se enriquecen, alteran o se matizan los elementos visuales al invadir el campo textual y cómo se vuelcan los ingredientes textuales en el espacio visual (Cid, 2016, p. 2).

En este recorrido por los autores que han contribuido a la discusión sobre la écfrasis y las relaciones entre literatura y artes plásticas o visuales, es necesario recurrir a Heffernan -citado por Pimentel- al referirse a la definición de écfrasis y enuncia que "de manera un tanto más abstracta la écfrasis es para Heffernan la representación verbal de una representación visual" (Pimentel, 2003, p. 206) y que resulta muy difícil imaginar una historia del arte desprovista de composiciones ecfrásticas, esto es, sin representaciones verbales de otras representaciones, las visuales, que constituyen el objeto de estudio de dicha historia. Años después, Clüver (1997), refiriéndose a la écfrasis, expuso que es "la representación verbal de un texto real o ficticio compuesto en un sistema sígnico no verbal" (p. 26). Es notorio que estos autores destacan el sentido representacional del proceso ecfrástico, de modo que si el texto verbal asume la representación de un objeto de artes visuales, entonces se establece una relación intertextual. Si se entiende la intertextualidad, en este sentido, como una representación verbal de una representación visual, Wagner (1996) planteó que se forma una "relación de intermedialidad" (p. 17). Pimentel añadirá al respecto:

La relación intermedial pone en juego por lo menos dos medios de significación y de representación. En el caso del objeto plástico citado; en su relación con el texto verbal la imagen evocada puede desembocar en un verdadero iconotexto: no solo la representación verbal es leída/escrita - de hecho descrita - como texto, sino que al entrar en relaciones significantes con el verbal le añade a este último formas de significación sintética que son del orden de lo icónico y de lo plástico - de hecho una suerte de incremento icónico -, construyendo un texto complejo en el que no se puede separar lo verbal de lo visual: un iconotexto (2012, p. 309).

En la actualidad la écfrasis desestabiliza las rígidas divisiones entre la literatura y las artes visuales, desarrollando un doble carácter intertextual, debido a que representa un objeto de otro medio de expresión y a la vez, se apropia de terminologías y conceptos descriptivos que pertenecen a la historia del arte como disciplina.

Elsner (2002) por su parte, propuso desplazar la definición de écfrasis, que se consideraba canónica en la modernidad, para entenderla como "la representación verbal de una representación visual" (p. 12). Dicha propuesta amplía el campo aplicativo de esta categoría, haciéndola extensiva no solo a la literatura, la poética, la historia del arte y la crítica, sino a las prácticas culturales. En concordancia con esta idea, es interesante destacar que, si se analiza la écfrasis como práctica cultural, entonces las imágenes pueden leerse como si fueran textos y los textos como si fueran imágenes (Schneck, 1999).

Continuando con esta visión interartística de la écfrasis, es necesario hacer una aproximación a los fundamentos señalados recientemente por Ponce Cárdenas (2014). Tomando como objetos de estudio poemas españoles contemporáneos consagrados a la evocación de una pintura concreta, este académico realiza un recorrido visual y verbal a través de los géneros: naturaleza muerta, paisaje, retrato, escenas de costumbre y pintura histórica, para que el lector pueda entablar un diálogo entre el texto literario y las fuentes icónicas, lo cual es posible estéticamente a través de la écfrasis.

Luego de enunciar los matices que presenta la relación texto/imagen, introduce un análisis de lo que ha Ilamado "pinacoteca verbal" (Ponce, 2014, p. 27), que es en esencia la manera en la que está dispuesto y organizado el texto estructuralmente, la forma en que se encuentra montada la novela y la manera en que se inserta el corpus de obras seleccionadas. "Una vez seleccionados los cuadros que 
se van a evocar por medio de la transposición de arte, el poeta debe decidir cuál va a ser la organización, la arquitectura textual del volumen concebido como una suerte de pinacoteca en verso" (Ponce, 2014 , p. 27). Desde este enfoque se puede interpretar que el autor de textos ecfrásticos asume un doble rol: se convierte en curador de obras de artes visuales y escritor de un texto literario. Con ello el crítico enfatiza que "La dispositio del poemario se constituye en reflejo verbal de la organización propia de un museo o una colección" (Ponce, 2014, p. 28), a la vez que propone comprender el texto ecfrástico a partir de una organización museográfica. Vale destacar que el curador es un investigador o un estudioso que entre sus funciones tiene el poder legitimador de obras de arte. Puede imponer obras, nombres y técnicas, seleccionar obras, dar forma al catálogo, dialogar y negociar con los patrocinadores y otros. El curador crea su propia obra (la muestra) a partir de obras existentes.

Por último, Pimentel (2012) definió la écfrasis metaléptica, categoría que rige este análisis literario, como el desborde del impulso plástico y las transgresiones del nivel narrativo al que pertenece. Los personajes del cuadro descrito se animan y salen del marco que delimita su existencia ficcional como objetos plásticos para interactuar con el otro mundo ficcional del cual, supuestamente, eran solo ornamento.

\section{INTERTEXTUALIDAD (INTERMEDIALIDAD)}

Una novelista en el Museo del Louvre es una novela que establece una interesante y recíproca relación entre palabras e imágenes. Las obras de arte -a diferencia de lo que pudiera pensarse- aquí no son empleadas para ilustrar la escritura, sino que sucede todo lo contrario; puede asumirse que el lenguaje visual es el detonante de una narratividad sui generis, causa principal -a modo de ver de quien escribe- por la cual dicha novela no ha sido analizada desde ninguna perspectiva por la crítica literaria. En ella, ambas expresiones de las artes se complementan y se potencian, entregando a medida que avanza la trama una lectura que -más allá de la hibridez e intertextualidad explícitas- se torna cada vez más sugestiva, dinámica e instructiva, debido a las múltiples posibilidades interpretativas que despliega. En adelante se demostrará que la relación "tanto referencial como representacional con un objeto plástico que el propio texto propone como autónomo, como otro con respecto al discurso que intenta representarlo" (Pimentel, 2003, p. 285) induce a una lectura iconotextual.

La intertextualidad es el mecanismo principal a partir del cual se configura la écfrasis, siendo de vital importancia en la tradición literaria. La écfrasis literaria se basa en una idea previa de la obra artística, en un supuesto, en lugares comunes o juicios de valor a propósito del artista, ya existentes y establece una relación contextual al hacer que las obras de arte participen del entramado discursivo.

La novela de Valdés es concebida como un relato intertextual en varios niveles. Este carácter no solo es notorio por el empleo constante del recurso ecfrástico, sino además porque la autora -inspirada en el legado de su autor favorito, Manuel Mujica Láinez (1910-1984), y con el propósito de rendirle tributo- desde el propio título de su novela establece diálogo con el libro de cuentos del escritor argentino Un novelista en el Museo del Prado (1984); indicio este que condiciona la lectura posterior, a la vez que amplía el corpus de textos que ponen en tensión el mundo plástico y el literario.

Ahora bien, en el plano analítico la écfrasis facilita a la autora confeccionar una obra ficcional en la cual la alusión cumple un papel fundamental, en tanto la vincula con el propósito clásico de atribuir al lenguaje literario la capacidad de "hacer ver" obras de arte con una finalidad que supera los límites del relato novelesco. Pero no es "hacer ver" en su sentido literal, sino desde un enfoque utilitario que posibilita una toma de posición política, inclusive con aquellas problemáticas propias del ser cubano. En correspondencia con la propuesta de Michael Riffaterre (2000), se tendría que señalar que las obras de arte aludidas como parte del decorado también tienen una función simbólica que incluso motiva actos y emociones que van desplegando la novela en un juego interartístico.

Como se puede apreciar, el ejercicio escritural de Valdés se construye sobre esta base teórica, pues pone en correlación dos medios de significación 
y representación a partir de la cita de varias obras importantes en la historia del arte universal reunidas en este reconocido museo. En la relación entre las obras citadas y el texto literario, los cuadros se convierten en "iconotextos" (Wagner, 1996) que invitan al lector a realizar, por lo tanto, una lectura iconotextual. En este entorno la autora se sirve de la écfrasis como recurso de aproximación a la imagen, de la que se apropia creativamente y la pone al servicio de los fines propiamente literarios que subyacen a la estetización de la práctica argumentativa, logrando que la descripción de las obras de artes visuales no solo pueda leerse como texto, sino que le atribuye significaciones de carácter icónico y plástico al texto verbal. Así, ambos textos son inseparables y "la écfrasis participa de una verdadera búsqueda ilusionista. Un ilusionismo que, añadamos aquí, participa de la vocación representacional, tanto de la literatura como de la pintura" (Giraldo, 2015, p. 205).

La historia se desencadena a partir de la visita que realiza la novelista (voz narrativa) al prestigioso Museo del Louvre. Tras ser perseguida por el guardián de la institución, persuadiéndola de que estaba cerrado, ella cae y se golpea la cabeza; detalle que condiciona el desarrollo del relato y certifica que -aun cuando la novela en su concepción general es postmoderna- la autora se vale de esta aplicación característica de la literatura modernista para evadir la realidad, para escapar de las circunstancias espacio-temporales que atravesaba y poder desplegar su escritura. Valdés (2009) escribe: "nunca más he podido salir del Museo del Louvre desde entonces; desde el año 1983 resido y convivo con los espectros dibujados o cincelados" (p. 17). A partir de este momento, la novelista -o en su defecto el yo narrador- queda atrapada en el interior del museo y se transforma en testigo y protagonista de lo que sucede con las obras de arte distribuidas en las distintas colecciones y salas del Louvre. Otro indicio importante es el referente al año, que atribuye cierto sentido autobiográfico al relato, debido a que desde 1983 Valdés residió en la capital francesa en calidad de técnica de la Oficina Cultural de Cuba en la UNESCO y como digna admiradora de los museos en general, en este caso particular, del Museo del Louvre, asume la fecha del primer año que residió fuera de la isla para situar su discurso narrativo. A pesar de que en este punto la lectura es muy incipiente y aun no se alcanza a tener claridad de lo que sucederá en las páginas siguientes, sí es evidente que la escritura estará mediada por la relación texto/imagen cuando la escritora expone:

Durante veinticinco horas o veinticinco años, en fin, durante este tiempo literario; no sólo he visto las obras de arte del Museo del Louvre resistir durante el día, enmarcadas en sus cuadros, o inmóviles encima de los pedestales, aguantando ecuánimes exclamaciones de admiración o sonrisas irónicas hasta el aburrimiento, también han aguardado impasibles que los estudiantes las copien, y que los estudiosos se atrevan a acercarse con sus lupas, a criticar sus grietas, los desperfectos de una nariz, la ambigüedad de una sonrisa (p. 17).

Desde esta perspectiva, se va configurando la trama narratológica. La autora asume el rol de curadora de obras de artes visuales, realiza una selección acorde con sus intereses y crea a partir de esta colección general una colección alternativa o -en términos de Ponce Cárdenas- una "pinacoteca verbal". Es decir, establece una especie de juego de caja china, con el cual le atribuye a la novela el principio curatorial de una exposición. Entonces, se puede plantear que a partir de la visualidad que propone el texto literario, por un lado, contribuye a la idea de que las obras perduren no solo en su soporte físico, sino también a partir del lenguaje y por otro lado, los lectores asumen una dualidad de condición, se transforman en receptores de obras de arte. En adelante, se tratará de dilucidar los posibles propósitos que indujeron a la novelista cubana a estructurar su obra partiendo de una distribución museográfica en que la novela se construye como guion.

Este sugerente texto transgrede los límites entre la ficción y la realidad para poner en conocimientos del lector temáticas que están vinculadas a la vida de la autora: el exilio, los asuntos de género y la añoranza por su territorio originario. Estas preocupaciones las trabaja, entonces, en un contexto bien particular, en el museo, que asume -como señala Juan D. Cid Hidalgo- el carácter de dispositivo. En 
"Archivo y novela. Sobre la dimensión museal de la literatura latinoamericana" (2017) el crítico sostiene que "el museo comienza así a consagrarse como un dispositivo que selecciona, reúne, conserva, hospeda y sanciona aquello que culturalmente es valioso y que forma parte de lo que es definido como patrimonio inmaterial" (Cid, 2017a, p. 172).

La novela no busca representar las obras mediante el lenguaje verbal porque, en concordancia con lo planteado por Mitchell (1994), el lenguaje significa sin imitar, sino que se centra en construir un mundo ficcional denso, es decir, un mundo que asume la obra de arte para configurar un espacio interzona. $\mathrm{Al}$ modo borgeano, la narradora introduce elementos verosímiles para convencer y hacer parte de su historia al narratorio.

Los usos del lenguaje insertan al lector en un mundo fascinante, en el cual confluyen personajes de diversas épocas sociohistóricas que -salidos de los límites de las obras de arte universales- cobran autonomía, actividad que quiebra todo horizonte razonable de expectativas. Rodríguez (2009) señala: "he aquí una Zoé Valdés catárquica en lo estilístico, con un aplomo literario exquisito, atrevida incluso a jugar con el lenguaje según el cuadro y la época en cuestión en la que se sumerge" (online). Aun cuando pareciera que la trama carece de continuidad debido a que no narra una sola historia, ya que cada capítulo desde su propio subtítulo alude a una obra distinta y sobre la cual versará el argumento discursivo, la autoficción es el elemento unificador de ellas, pues desde su condición de narradora-curadora de productos de artes visuales, Valdés transforma su novela en una exhibición, en una exposición que instruye al lector sobre el conjunto de obras que apreciará. El guion museal -entonces- se funde con la novela de manera que las intenciones de uno son las intenciones del otro. Nieto Ruiz (2014) recuerda y precisa los límites de la actividad curatorial cuando señala:

La curaduría tradicional tiene por objetivo, pues, ser una estructura de mediación entre el artista y el público a través de un discurso que implique y refleje el conocimiento tanto del artista como de la colección, la selección de ésta y el ordenamiento que mejor muestre al público la tesis propuesta, sin dejar de lado los objetivos y la imagen del lugar en el que se exhibe. Una buena analogía es ver a la curaduría como una guía en el campo del arte que traza senderos para la interpretación de las obras, los movimientos y/o los artistas (p. 19).

En su mayoría, cuando Valdés hace referencia a una obra de las expuestas en las salas, proporciona algunos antecedentes o datos importantes del artista, de la época y de los personajes representados para ubicar al lector en el contexto y convidarlo a ser partícipe de este. En la novela se lee:

Con La balsa de la Medusa, Théodore Géricault inauguró el primer reportaje periodístico apoyado en la imagen. La tragedia de la balsa de la Medusa constituyó un hecho real: en 1819, el pintor impuso un realismo superior al magisterio de David oponiéndose en estilo al neoclasicismo. El duque de Orléans se convirtió en el principal comprador de toda su obra a partir de 1814 , pero este cuadro fue posteriormente adquirido por el Estado (p. 71).

El tenor especializado que se reconoce en este pasaje, que se repite prácticamente en todas las obras escogidas para construir el guion (la novela), sustenta la idea de que la novela se construye a partir de la curaduría del narrador. Por supuesto, en el origen mismo de la actividad curatorial se encuentran los criterios de interés que van guiando la conformación o selección de las obras. Se cree que en la novela de Valdés la práctica curatorial se encuentra asociada con el gusto estético y los intereses personales de la narradora, quien ha declarado en entrevistas públicas que sus visitas constantes al Museo del Louvre sucedieron cuando atravesaba una época de crisis, de falta de motivación e inspiración. Desde esta perspectiva, es posible asumir que el museo se transformó en una instancia de salud (Deleuze, 1996) para la novelista y en consecuencia, los artistas seleccionados se convirtieron en sus psicoterapeutas, ratificando el nivel de incidencia que posee la obra de arte sobre el estado anímico de los seres humanos. "La écfrasis como una práctica cultural Ileva aparejada el interrogante sobre su 
función concreta en cuanto práctica" (Gabrieloni, 2008, p. 104); de manera que, en este discurso -por lo ya planteado- puede asumirse que la écfrasis adquiere también una dimensión psicológica.

La colección de obras escogidas por la novelista reúne los principios de una exposición colectiva, en la cual converge una diversidad de autores, géneros y estilos de representación. Sin embargo, en una mirada panorámica, el conjunto de obras se adscribe a la corriente figurativa de las artes visuales. No obstante, pese a esta pluralidad, existen elementos que demuestran el privilegio que le da la narradoracuradora a las obras que asumen la representación de la figura humana como leitmotiv. En términos generales, es posible plantear que son dos las líneas temáticas principales sobre las cuales se proyecta esta colección: los retratos y las escenas mitológicas, donde en su mayoría se percibe la figura humana semidesnuda o desnuda; las obras de carácter histórico, que establecen un vínculo más directo, desde esta perspectiva de lectura, con la problemática también histórica de la migración cubana y el exilio.

La primera obra referida, con la cual se da inicio al guion, es La Gioconda o La Mona Lisa; gesto muy suspicaz de Valdés, ya que esta pintura es uno de los principales atractivos no solo del Louvre, sino de la historia del arte universal. Consciente de ello, escribe: "es un retrato demasiado visto, pero no hay persona que no desee volverlo a ver; es una imagen que crea adicción" (p. 21). Adicción que se debe a las polémicas que ha generado por años en el mundo de las artes por su exquisita factura, así como también por su enigmática sonrisa e incluso por la ambigüedad de género, llegando a considerarse la obra más famosa del mundo que consagró para siempre la celebridad de su autor. La narradora-curadora es enfática en su juicio respecto del cuadro cuando apunta: "La Gioconda es la obra perfecta, el nec plus ultra del retrato del Renacimiento. La ilusión trasciende la tela, la belleza supera al óleo para volverse más espiritual que carnal" (p. 22). Con esta obra paradigmática en la Historia del Arte instaura un primer elemento a desplegar a través de su práctica narrativa: el tema de la reivindicación y la ambigüedad de género. Este no es casual, pues constituye un punto de reflexión en casi toda la obra valdesiana. La mujer, a través de las imágenes, es instaurada en este discurso novelar para aliviarla del ultraje a que ha sido sometida a través de la historia, debido a los dogmas de cosificación y discriminación instituidos por la cultura patriarcal de la que ha sido víctima. En el relato se nota la postura feminista de Valdés desde disímiles perspectivas, por ejemplo: los juegos e impulsos sexuales, el sexo por mero placer, que deriva en escenas lésbicas y la maternidad como marca social identificativa de la fémina. Al respecto, Butler (2002), propone y analiza el tema del cuerpo asociado con la maternidad y posteriormente, Guerra (2006) aborda la idea del cuerpo embarazado como lo que carece de lenguaje propio.

De ese don natural que es la maternidad y sin embargo posee significados esencialistas para las sociedades falogocéntristas, Valdés habla en el segundo capítulo, a partir de la écfrasis que establece con la pintura Alegoría sobre la instalación del Museo en la Galería Grande del Louvre:

-Mamá, eres una danaide -afirma el tercer hermano.

- ¡No, no y no! ¡Es una odalisca! -grita enrabietado el cuarto hijo.

-No discutan, sólo soy vuestra madre. Sólo eso, cuido de ustedes. Trabajo, y me pongo a escribir de vez en cuando.

Una nube entra por la ventana, atraviesa el cristal, desciende a nuestra altura. Mis hijos se montan en ella, yo detrás. Nos acostamos abrazados encima de una mullida y esponjosa nube. ¡No puedo creerlo! (p. 31).

El énfasis expresivo demuestra una de las tantas formas en que es tratado el cuerpo femenino, en lo referente a la función biológica de dar vida y las funciones sociales que le competen. Por ende, este discurso no se limita a los cánones de la narrativa falogocéntrica, sino que desde la visualidad revela una abierta crítica feminista.

En otro momento textual, Valdés - desde la interdisciplinariedad, apoyada en el recurso ecfrástico- cuestiona la práctica de ver y asumir el cuerpo 
constituido de la mujer como un signo cultural. Para ello centra su mirada en la estética del cuerpo de la Odalisca morena y con un lenguaje coloquial resalta la desnudez y la postura de este: "la hormiga ha caído encima de una nalga rosada de la muchacha que descansa encima de una cama desordenada, con su fabuloso culo al aire y las piernas entreabier-

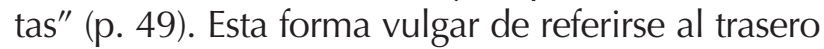
del personaje pictórico encierra un tono denunciatorio y cuestionador a la manera en que nombran a este componente corporal que, además, lo tienen codificado como objeto de placer los denominados sujetos masculinos.

El cuerpo es inscripto en este texto, desde su desnudez hasta la sexualidad a la que se expone, haciendo de la escritura una abierta reflexión que va más allá de los tabúes. Al respecto, Butler (2002), plantea lo siguiente: "El cuerpo implica mortalidad, vulnerabilidad, agencia: la piel y la carne nos exponen a la mirada de los otros pero también al contacto y a la violencia. El cuerpo también puede ser la agencia y el instrumento de todo esto, o el lugar donde 'el hacer' $y$ 'el ser hecho' se tornan equívocos”' (p. 40).

En su sexto capítulo, son dos obras del pintor francés Jean Honoré Fragonard ("El pestillo" y "El cerrojo y la camisa quitada"), las que se convierten en el foco de atención de Valdés, para "contaminar" su escritura y así desacralizar el estigma de la sociedad patriarcal que considera a la mujer como un objeto de placer.

Él le ruega a ella que le entregue su virginidad, ella finge que jamás se la dará, negada por los convencionalismos, sus padres, la familia. Todo ese tonteo para acabar con las piernas abiertas dentro de media hora, como mucho, iqué digo!, antes de quince minutos ya se ha levantado el vestido. Él es quien se quita la camisa un poco tarde (...).

La chica detrás de mí me besa la nuca, y su lengua discurre en mi oreja. Todo eso es absurdo, pero me gusta, me da un placer vertiginoso, que sube desde mis pantorrillas hacia mi garganta, y se me llena de burbujas la boca. Permanezco, sin embargo, in- móvil. Temerosa de hacer algún ruido y de romper el encantamiento (p. 53).

La reflexión paralela que realiza desde las relaciones sexuales y amorosas no solo entre dos, sino desde una mentalidad desinhibida y transgresora, compuesta por tres, se constituye como un mecanismo más para denunciar explícitamente la azarosa historia de objeto que ha vivido la mujer durante siglos. Para sustentar este planteamiento es meritorio señalar la idea expuesta por Aiello (2013):

En su discurso narrativo las reflexiones de la voz narrativa y de sus personajes sobre el deseo erótico de la mujer reconoce el vínculo intrínseco entre la sexualidad y el sentido de identidad tan importante para la mujer, en oposición a lo que históricamente el cuerpo femenino se ha reprimido y al doble modelo de moralidad que ha estado vigente y que aún prevalece en muchas de nuestras culturas (p. 9).

Es así como se puede aseverar que esta novela, a pesar de su manera compleja de escritura -concebida desde dos planos discursivos distintos interconectados- tan distinta al tono más explícito de la reflexión de género propuesta en sus otros textos, de igual modo tiene gran significación como discurso feminista, pues al realizar este gesto, la novelista no solo deja inscrito en la representación literaria la voz y el ser silenciado de la mujer, sino que a su vez está escapando a la situación de víctima, ya que es su obra el medio por el cual busca romper con la verticalidad del poder.

El segundo punto temático que unifica conceptualmente varios cuadros de la colección curatoriados por la novelista es el vinculado con sucesos históricos universales, que -sin embargo- desde esta perspectiva dan cuenta de la realidad socio-política cubana. Esta iconicidad se complementa con alusiones en la diégesis de la novela, que son muestras tácitas de la nostalgia que siente la narradora por su madre tierra y lo difícil que se le hace prescindir completamente de esos rasgos melancólicos.

En el texto existe una intención por textualizar desde la ficción, tomando como referente obras de arte, una realidad social -la cubana-, pues la escritora 
ha sufrido las consecuencias de la rebeldía frente al poder hegemónico castrista que la ha perseguido y condenado, al igual que a otros tantos cubanos en diáspora forzada. En este contexto, Valdés no pierde la ocasión para arremeter contra el discurso social y político instaurado hace más de cincuenta años en la isla. La novelista en su sitio web (zoevaldes. org) realiza una crítica fuerte al sistema de gobierno cubano y desde aquí mantiene su posición de animadora permanente de la posibilidad de cambio radical.

Entre las obras más significativas dentro de la curaduría construida, que pone en el tapiz el tema de la libertad anhelada por todo un pueblo, se encuentra La Libertad guiando al pueblo, que presenta un tema netamente histórico, en tanto muestra un suceso verídico para la historia de Francia que estuvo marcado por el deseo de emancipación y autonomía. Sin dudas esa carga semántica del cuadro y los calificativos asociados con ella se corresponden y son contextualizables con los anhelos de la sociedad cubana marginada, en la que predominan las restricciones, la represión y la censura, entre otros. No es azaroso que en la escritura enfatice en la palabra "libertad" planteando: "La libertad guía, armada de una bayoneta, e insta a que los hombres, las mujeres y los niños la sigan" (p. 16). La novelista, como colofón para este discurso eminentemente denunciatorio, dice: "La obra posee un movimiento cinematográfico piramidal. Es una pirámide de cuerpos hambrientos de libertad" (p. 16). Con esta metáfora final resume el principal nudo temático de la obra visual y exalta el sentimiento de dos territorios que, en distintos momentos históricos y circunstancias desiguales, se pueden emparentar, pues el móvil de lucha de sus connacionales es el mismo: la libertad que -por demás- es un derecho inalienable de todo ser humano.

Otro exponente que aporta iconicidad al relato es "La balsa de la Medusa", obra referencial sobre un suceso real, cuyos elementos composicionales posibilitan establecer un intertexto con la realidad sociopolítica cubana, específicamente en lo referente a las migraciones ilegales y casi masivas que se han estado sucediendo por muchos años desde Cuba hacia Estados Unidos, siendo ya casi un cliché respecto de la diáspora cubana. La narradora, cons- ciente de esto, se apoya en la écfrasis para presentar una metáfora épica de esta realidad.

Parada ante la inmensa obra de Géricault no puedo evitar la perplejidad, una y otra vez, la desesperación de esas personas luchando por la vida, en medio de un mar revuelto, me es sumamente familiar. Los cuerpos apilados, algunos a punto de caer al agua, otros ya muertos, los cuerpos descolgados hacia lo profundo del océano, otras figuras aún con los brazos apuntando a un horizonte imaginado, soñado quizás (p. 72).

Con este fragmento es importante destacar que, desde la interconexión entre las artes (visuales y literarias), Valdés describe esta dimensión histórica que es el denominado sueño americano o en inglés, the American dream; sueño que ha movilizado y costado la vida a miles de cubanos, los cuales en balsas abandonan la isla -así como lo refleja esta pintura con la cual se asocia en la trama novelar-y emprenden esta travesía extremadamente peligrosa, persiguiendo la libertad e igualdad de oportunidades. Por tales motivos, este discurso narrativo, sin perder la esencia ficcional, se torna revelador de una perspectiva sociopolítica que afecta al pueblo cubano, condenado al silencio y la doble moral. La autora no puede desligarse del compromiso social con su pueblo natal, con sus paisanos. Por eso, desde la escritura, desacraliza un discurso político oficial, en aras de reivindicar una realidad que ha sido manipulada por más de cincuenta años. La apuesta al todo o nada, la búsqueda de apenas una posibilidad, de una esperanza mínima de salvación induce a los cubanos a desafiar la fuerza de la naturaleza, los miedos físicos, psicológicos y simbólicos, elementos que atribuyen un carácter heroico y épico a estas travesías.

Como se ha ido demostrando, la representación según como la propone esta novela- "es un proceso por medio del cual el lenguaje construye y vehicula significados con distintos grados de referencialidad y de iconicidad" (Pimentel, 2012, p. 314). La novelista, víctima también de esa realidad cubana convulsa que critica fervientemente, conforma desde el exilio un universo narrativo determinado 
por lo ficcional, pero en el cual plasma referencias plásticas universales muy explícitas vinculadas con su rechazo a ese gobierno dictatorial (como ella lo denomina), ratificando con su técnica narrativa que "toda representación verbal contiene una serie de indicios de aquello a lo que puede relacionarse, y que constituye los elementos tanto de su contextualización como de su recontextualización" (Pimentel, 2012 , p. 317). Pero no son solo los elementos expuestos los que evidencian que la novelista no logra despojarse de un pasado que marcó huellas indelebles en su vida. Hacia el fin de la novela, en el último capítulo, concluye no solo el relato, sino que sintetiza de un modo ingenioso y sorprendente su vida de añoranzas. Su imaginación superpone dos realidades (La Habana y París). "Iba a cruzar la calle Línea hacia la otra esquina de $M$, en el Vedado, llevaba a mi hija de la mano. Entonces mis ojos parpadeaban, mi visión cambiaba, y detrás de un conjunto de árboles divisaba el Arco de Triunfo de París" (p. 172). Estas líneas ratifican que cuando la persona por circunstancias diversas ha tenido que abandonar sus orígenes y asimilar un proceso de aculturación -pese a vivir en un presente inmediato, totalmente distinto a lo que fue su vida pretérita- le resulta imposible desdeñar ese cúmulo de recuerdos y en este caso específico, la escritura es el medio idóneo que posibilita a la narradora yuxtaponer sus sentimientos, mantener los recuerdos, su memoria, como cuadros de una exposición, en un museo de palabras.

\section{LA ÉCFRASIS METALÉPTICA: RECURSO DE CONTAMINACIÓN INTERARTÍSTICA}

La dinamización originada en esta escritura por el proceso ecfrástico es impresionante. Las transgresiones entre la ficción y la realidad ofrecen un "incremento icónico" (Pimentel, 2012, p. 312) que permite ampliar el espectro de significación y posibilidades de lecturas al texto, es decir, "dotando de vida al relato". Esta idea fue sustentada por los autores progymnasmata (Teón, Aftonio, Hermógenes y Nicolao), quienes señalaban que el rasgo esencial de la écfrasis era dotar de vida al relato, acercándolo al lector (recuperado de Lozano-Renieblas, 2005).

Por su parte, Cid Hidalgo apunta (2017b) que Una novelista en el Museo del Louvre de Zoé Valdés "rompe con la dimensión estática del museo que congela, santifica y colecciona obras para, en un trabajo delicado y violento a la vez, otorgarles movimiento y vida" (p. 58). Desde esta perspectiva, en el último episodio referido, se lee:
Alberto me pasó el brazo encima de los hombros. Ya no era el pintor, tal como lo habíamos visto salir de su autorretrato, aho- ra era un joven judío, se llamaba Ilam, y aunque su cara era la misma que la de Du- rero ya no estaba vestido igual, ni llevaba el cabello largo (p. 173).

Con ello es notorio que la écfrasis metaléptica, además de "dar vida al relato", es el recurso que moviliza la narración, pues propicia que se superponga la identidad del pintor Alberto Durero con la de Ilam, el primer amor de la novelista, con lo cual se funden los límites de los distintos planos narrativos. La ficción dentro de la ficción pierde sus atributos, dando paso al despliegue de un lugar en que no existen privilegios ni estatus canónicos o al menos donde los estatus son reversibles: las visitas del museo asumen los lugares de los personajes que han salido de su "cárcel de paspartú" (Cid, 2017b, p. 58).

Zoé Valdés convida al lector a entrar en un mundo fantástico de penumbras y claroscuros en el cual los personajes de las obras del Museo del Louvre adquieren vida, se pasan de un soporte a otro e interactúan con la novelista que vive en el interior del museo parisino.

He percibido cómo, no solo durante la noche, intercambian sus puestos, salen los personajes a caminar o a bailar en las galerías centrales, conversan entre ellos, sin importarles estilos o épocas; por cierto, y esto es lo novedoso, en múltiples ocasiones, incluso de día y con las salas abarrotadas de visitantes, los personajes de los cuadros han abandonado al instante sus puestos (desde luego han sabido elegir a sus sustitutos, que han sido los propios asiduos al museo o visitantes extranjeros) (p. 17).

La narradora realiza un despliegue gozoso, haciendo que los personajes de las obras abandonen 
-inusitadamente- las posiciones que les fueron atribuidas por sus artistas ejecutores y que están delimitadas por el marco. Además, combina el sentido eminentemente crítico con el carácter lúdico, con la alegría que la caracteriza a ella y a los habitantes de su tierra natal caribeña, para de algún modo tergiversar la idea del museo como un espacio sacralizado y de culto a las obras de arte inmovilizadas.

El museo dinámico al que se refería Alfonso Reyes se instala a través de la experiencia de la novelista -quien selecciona el material de archivo (los enunciados según Foucault)que transita por aquel museo fantasmal que adviene por momentos museo-circo o museo-zoológico debido al carácter que van asumiendo los cuadros y sus relatos, los archivos y sus pruebas, la memoria y su perdurabilidad (Cid, 2017b, p. 58).

Valdés no descuida este sentido lúdico a lo largo de toda la obra. Desde su escritura defiende el entusiasmo y la jovialidad de los cubanos, haciéndolo notar en varios fragmentos, como cuando enuncia la aparición de la cantante Madonna, la cual durante su estadía en el museo es confundida con Esther, la protagonista de la obra pictórica que lleva por título "El baño de Esther". "La Ambición Rubia [una manera de nombrar a la cantante Madonna], mientras entona una de sus más populares canciones, repara en Desdémona, le sonríe, guiña pícara un ojo, la invita a subir al cuadro que ella ha convertido en escenario" (p. 100). Aquí, como en casi toda la novela, se rebasan los límites del paspartú debido a la mezcla confusa o extraña entre los personajes 'reales' y los 'pictóricos'.

Estos elementos revelan que el impulso narrativo de Valdés transgrede los márgenes de los objetos plásticos citados, porque los personajes de las obras salen de sus límites y se insertan en ese otro mundo ficcional del que aparentemente ellos eran la ficción. Cuando la novelista en el capítulo "Reflejo de luna en el ojo de una odalisca" alude a los cuadros de "La gran odalisca" y "El sueño de Endimión", de Ingres y de Girodet respectivamente, desde su escritura propicia el intercambio y el coqueteo de los personajes de ambas pinturas, extrayendo a Endimión del marco que delimita la obra que él prota- goniza, para trasladarse hacia donde está situada la Odalisca y declararle su amor.

Cupido posa sus labios en la frente de Endimión, enseguida moja sus labios con un racimo de fresas salvajes que gotean rocío. Endimión se despereza, desciende del marco de su cuadro, y atraviesa como Dios lo trajo al mundo los salones del museo (...) El hombre se sitúa frente a la Odalisca; aún resplandece en su costado el rayo de luna. Tiende una mano hacia la mujer. - Te amo, Odalisca - le declara su amor (p. 69).

La desestabilización de la relación realidad-ficción y de paso del mundo novelesco que el lector había "interpretado como realidad se 'desrealiza' para convertirse en ficción con respecto a una realidad que antes se había leído como ficción" (Pimentel, 2012, p. 345). Estos personajes, al igual que sucede con otras escenas plasmadas a lo largo de la novela, desplazan las fronteras de su mundo pictórico y se instalan en otro plano de realidad: el de la diégesis circundante.

La representación verbal de obras de artes visuales es asumida por Valdés como un proceso en que el lenguaje se comporta como "una estructura de mediación" (Pimentel, 2012, p. 314). Desde este enfoque de lectura, el capítulo "La orgía suicida de Sardanápalo" es un ejemplo significativo que, más allá de la alusión a la pintura "La muerte de Sardanápalo", inserta en la narración datos que se vinculan con la historia de su origen. Esto justifica la aparición repentina del escritor Lord Byron en el museo, colmado de orgullo por ser el inspirador de Delacroix. La narradora establece diálogo con Byron y de pronto:

El poeta me toma bruscamente por los brazos, de la misma manera en que uno de los guardias al pie del lecho del rey toma a una de las amantes, y como a ella me obliga a arrodillarme, de espaldas a él. Tironea de mi ropa, me desviste a la fuerza. Y completamente desnuda me lanza al interior de la obra. Caigo en la misma posición que Myrrha, la he reemplazado; sólo me resta levantar la mirada para comprobar que Lord 
Byron se halla recostado, asumiendo la posición de Sardanápalo (p. 80).

En el desborde narrativo, refiere la novelista que han pasado varios días y "sorpresivamente, entre el numeroso público que ha pasado a visitar esta obra, avizora el rostro fresco y hermoso de una señorita" (p. 80), quien confiesa a una amiga que se ha enamorado del rey de Nínive (Sardanápalo). "¿Cómo puedes decir que amas a un personaje de un cuadro? ¿Estás loca?" (p. 81). Lo planteado hasta el momento va dejando entrever que en el propio acto de escritura, la novelista no solo selecciona, sino resignifica el objeto que representa a partir de la écfrasis metaléptica como subgénero literario que posibilita la contaminación interartística. La escena continúa:

Aprovecho y le cedo a la joven el puesto de Myrrha. Sucedió muy fácil, bastó que el espíritu inflamado de Sardanápalo se lo pidiera a Lord Byron, con tal vehemencia, que me veo expulsada del cuadro y en mi lugar a la recién llegada (p. 81).

La écfrasis metaléptica, entonces, configura una escritura en la cual los personajes de las obras de arte superan, quebrantan y vulneran la frontera del contexto que los define, a la vez que los visitantes al museo se sumergen en ese mundo iconológico que veían como ficción. Ello provoca que el montaje de la ficción asuma un rol clave en el derrumbe de los convencionalismos de ambas ficciones entrelazadas: lo pictórico y lo narrativo.

En otro momento, específicamente en el capítulo "Las sombras del maestro y su discípulo", la écfrasis desarrollada produce una simbiosis narrativa que además aumenta su iconicidad. El relato plasma:

Entre esa marea de visitantes que no se detiene jamás, creo ver a La musa de Virgilio, también Ilamada La lectora con guirnalda de flores (1845) pintada por Jean-Baptiste Corot y fugada de su cuadro. Le digo al menos cierre su vestido, porque eso de que en el cuadro aparezca con el corpiño afuera está bien, porque ya no estamos en el cuadro (p. 89).
Una vez que la autora entrega esta serie de datos acerca de la obra pictórica con la cual trabaja, convoca al lector-receptor a establecer vínculos y alianzas, lo incita a buscar el referente visual. Esta relación que se establece entre ambas representaciones (la literaria y la visual) es de intermedialidad, ya que la imagen evocada se convierte en iconotexto que -al entrar en relaciones significantes con el texto verbal- imposibilita que ambas materializaciones puedan separarse, lo que en consecuencia produce un incremento icónico. En este ejemplo, la musa se escapa de la obra pictórica que protagoniza y se incorpora a la oleada de visitantes, cual si fuese una más del público, distorsionando -de esta maneralas posiciones habituales en las cuales se inscribe.

La écfrasis metaléptica es empleada como recurso literario mediador que origina y confunde el estatuto diegético de las figuras de las obras de artes visuales y de los personajes, haciendo que el lector vacile sobre el mundo que lo circunda, en el cual participa. Al recrear el escape de las figuras que protagonizan las obras de artes visuales de sus marcos delimitantes, es decir, cuando abandonan el paspartú que las guarda y preserva como bienes artísticos, Valdés establece una metáfora irónica con la idea de la huida y la búsqueda de la libertad plena del pueblo cubano. Los personajes ficcionales encarnan el deseo de todo un pueblo. Ellos -así como los cubanos reales- se empeñan en salir de la cárcel que enmarca su existencia física y los priva de la libertad plena. Los personajes se escapan de la cárcel del paspartú, así como los cubanos se van de su isla querida.

\section{CONCLUSIONES}

Al cierre de la presente investigación es imprescindible señalar que este análisis es el primero que se efectúa a Una novelista en el Museo del Louvre desde un enfoque académico que privilegia el desarrollo y materialización desde la interzona literaria y plástica. Su ejecución representó un gran desafío y se constituyó como una propuesta crítica de acercamiento intermedial al fenómeno descriptivo de las obras de artes plásticas realizado a partir del recurso estilístico de la écfrasis. 
A la luz de estas líneas de acceso a la novela, se constataron las peculiaridades del texto estudiado respecto de las otras obras de la autora cubana. El principio de la intertextualidad, mediado por la écfrasis, la alusión en el título al trabajo del argentino Manuel Mujica Láinez, la referencia directa a escuelas artísticas, temáticas y a vocabulario "técni$\mathrm{Co}^{\prime \prime}$ del mundo de las artes plásticas, dotan al texto de un espesor que viene a distanciar la novela de las otras producciones de la autora, a la vez que viene a sostener la competencia de la escritora en las zonas en que se mueve, desde donde da por sentado la necesidad del contagio interartístico. Por estas razones es posible creer que la noción curatorial fue clave para comprender el trabajo de selección y montaje de los distintos estímulos visuales que se fueron incorporando en el flujo de la novela. La narradora deviene, entonces, curadora de artes visuales y por lo tanto, creadora de un espacio de representación literaria que se va constituyendo en una especie de guion museográfico. El texto seduce e instruye al lector no solo en el nivel alegórico (el problema de "lo cubano"), sino también en el trabajo de exégesis plástica de las distintas obras. Con ello logra atribuirle al lector el rol de receptor "creativo", debido a que ambos comparten la focalización propuesta por la narradora en que la novela pareciera transformarse en la curaduría de una gran exposición.

La presencia de la écfrasis metaléptica, entendida como recurso retórico e intermedial, determina y configura la escritura, dotando de cierto carácter lúdico a la ficción plástica esbozada, a la vez que posibilita ampliar el rango de la exégesis. Por lo pronto posibilitó dinamizar el relato y el espacio museal tradicionalmente pensado desde la inmovilidad. Los personajes de las obras de arte se desplazan de sus posiciones ficcionales y se insertan en el mundo real presentado por la novela, intercambiando puestos con los personajes de la supuesta realidad e incluso con la propia novelista. Es decir, se transgrede el orden habitual y natural de ambos espacios y también, al narrar obras de artes plásticas o visuales significativas para la Historia del Arte Universal, incentiva al lector a activar sus redes de referencia y proyectar los conocimientos culturales que posee en un proceso de lectura dinámico. La relación intertextual o intermedial establecida entre la representación literaria y la visual, entonces, es de carácter contributivo, porque las imágenes que se evocan mediante la escritura se transforman en iconotextos que incrementan el valor icónico del discurso.

Un sello distintivo de la escritura de Valdés es su condición exiliar. Es en este contexto que la novela proyecta su posición frente al fenómeno de la diáspora y el castrismo con un fuerte sentido crítico, todo ello textualizado esencialmente cuando aborda sus preocupaciones referentes al género (la maternidad y el cuerpo desnudo de la mujer como objeto de placer sexual), así como la situación socioeconómica y política (carencias económicas y falta de libertad) que condiciona las migraciones masivas que tienen lugar en el contexto cubano. Esta modalidad adoptada convierte su discurso en un mecanismo a través del cual busca subvertir el poder.

La construcción del guion museográfico, en que deviene la novela, se organiza a partir de una selección interesada de los archivos que son instrumentales al interés último de la composición; es decir, va construyendo una discursividad crítica que alcanza planos superiores a los meramente estéticos. La crítica al sistema impuesto por Fidel Castro y la revolución cubana, la falta de garantías individuales, la represión permanente, la falta de libertad, la imagen de la mujer, etcétera, parecieran ser los temas hilvanados en ese guion museográfico que viene a debilitar al máximo los límites disciplinarios tradicionales asociados con el género novela.

\section{REFERENCIAS BIBLIOGRÁFICAS}

Agudelo Rendón, P.A. (2012). Entre realidad y ficción. La écfrasis literaria en "El engañoso cuadro" de Pedro Gómez Valderrama. Recuperado de http://publicaciones.eafit.edu.co/index.php/ co-herencia/article/viewFile/1764/1761.

Aiello, A.J. (2013). El discurso narrativo de Zoé Valdés: Una escritura metaficcional. Recuperado de http://www.academia.edu/2759140/ El_discurso_narrativo_de_Zo\%C3\%A9_ Vald\%C3\%A9s_Una_escritura_metaficcional. 
Alberdi, B. (2016). Escribir la imagen: la literatura a través de la écfrasis. Literatura y Lingüística, 33, 17-38.

Butler, J. (2002). Cuerpos que importan: sobre los límites materiales y discursivos del "sexo". Buenos Aires: Paidós.

Cid Hidalgo, J.D. (2016). Programa de asignatura "Imágenes textuales y textos pictoriales". [Código 4223119. Doctorado en Literatura Latinoamericana. Semestre 1-2016]. Concepción: Universidad de Concepción.

Cid Hidalgo, J.D. (2017a). Archivo y novela. Sobre la dimensión museal de la literatura latinoamericana. Literatura y Lingüística, 35, 159-178.

Cid Hidalgo, J.D. (2017b). Museo, novela, archivo. Aproximación a los museos de papel. Atenea, 515, 47-61.

Clüver, C. (1997). Ekphrasis reconsidered. On verbal representations of non-verbal Texts. U. B. Lagerroth, H. Lund and E. Hedling (edit) Interart poetics. Essays on the interrelations of the Arts and Media. Amsterdam: Rodopi.

Deleuze, G. (1996). Crítica y clínica. Barcelona: Editorial Anagrama.

Elsner, J.R. (2002). Introduction: The Genres of Ekphrasis. Ramus 31, 1-18.

Gabrieloni, A.L. (2008). Écfrasis. Eadem Utraque Europa. 4(6), 83-108.

Giraldo, E. (2015). Entrar en los cuadros. Écfrasis literaria y écfrasis crítica en los ensayos de Pedro Gómez Valderrama. Recuperado de http://publicaciones.eafit.edu.co/index.php/co-herencia/article/view/2979

Guerra, L. (2006). La mujer fragmentada: historias de un signo. Santiago de Chile: Cuarto Propio.

Heffernan, J. A. W. (1993). Museam of World. The Poetics of Ekphrasis from Homer to Ashbery. Chicago y Londres: The Universiy of Chicago Press.
Krieger, M. (1967). The Ekphrastic Principle and the Still Movement of Poetry; or Laoköon Revisited. The Play and Place of Criticism. Baltimore and London: The John Hopkins University Press.

Lozano-Renieblas, I. (2005). La écfrasis de los ejércitos o los límites de la enárgeia. Recuperado de http://revistas.um.es/monteagudo/article/ view/77221

Mitchell, W. J. T. (1994). Picture Theory: Essays on Verbal and Visual Representation. Chicago: University of Chicago Press.

Nieto Ruiz, C. (2014). Historia de una actitud ante la forma. De la curaduría tradicional a la curaduría artística. Recuperado de https://books.google.cl

Pimentel, L.A. (2003). Écfrasis y lecturas iconotextuales. Recuperado de http://www.lpimentel.filos.unam.mx/sites/default/files/poligrafias/4/13luz-aurora-pimentel.pdf

Pimentel, L.A. (2012). Écfrasis: el problema de la iconotextualidad y de la representación verbal. En Constelaciones I. Ensayos sobre Teoría narrativa y Literatura comparada. México: Bonilla Artigas Editores.

Ponce Cárdenas, J. (2014). Écfrasis: visión y escritura. Madrid: Editorial Fragua.

Riffaterre, M. (2000). La ilusión de écfrasis. Literatura y pintura. Antonio Monegal (Comp). Madrid: Arco/Libros.

Rodríguez, J.C. (2009). Zoé Valdés se transforma en "Una novelista en el Museo del Louvre", en homenaje a Manuel Mujica Láinez. Recuperado de http://ecodiario.eleconomista.es/ libros/noticias/1655802/10/09/Zoe-Valdes-setransforma-en-Una-novelista-en-el-Museo-delLouvre-en-homenaje-a-Mujica-Lainez.html\#. Kku828teero6UVU.

Schneck, E.P. (1999). Pictorial desires and textual anxieties: modes of ekphrastic discourse in nineteenth-century American culture. Word \& Image 15(1), 54-62. 
Spitzer, L. (1962). The 'Ode on a Grecian Urn', or Content vs Metagrammar. En Anna Hatcher. (Ed.). Essays on English and American Literatute. Princeton: Princeton University Press.

Valdés, Z. (2009). Una novelista en el Museo del Louvre. Bogotá: Editorial Norma.

Wagner, P. (Ed.) (1996). Iconos - textos - iconotextos. Ensayos sobre écfrasis e intermedialidad. Berlín y Nueva York: Walter de Gruyter. 